\title{
POTENSI SARI LIDAH BUAYA DAN SARI LEMON DALAM MEREDUKSI FORMALIN PADA TAHU
}

\author{
Connie Daniela $^{1)}$, Herla Rusmarilin ${ }^{2)}$, Hotnida Sinaga ${ }^{3)}$ \\ 1) Pascasarjana Program Studi Ilmu Pangan, Fakultas Pertanian, Universitas Sumatera Utara, Medan \\ ${ }^{2), 3)}$ Dosen Ilmu Pangan, Fakultas Pertanian, Universitas Sumatera Utara, Medan \\ Email: conniedaniela83@gmail.com
}

\begin{abstract}
Formalin compounds that are carcinogenic, but often used as preservative tofu to extanding shelf life. This study aims to determine the effect of concentration and duration immersion of aloe vera and lemon in reducing formalin. Tofu first soaked 5\% formalin then added aloe vera and lemon juices. This experiment used completely randomized design consisting of two factors, concentration of aloe vera and lemon juices, 100\%:0\%, 80\%:20\%, 60\%:40\%, 40\%:60\%, 20\%:80\%, 0\%:100\% and immersion time 30, 60, 90 (minutes) and completely non factorial design, treatment for storage duration 0, 3, 6, 9 (days). The parameters used are formalin test using HPLC, protein, and total microbes. The sample on storage treatment is the greatest formaldehyde reduction. Formaldehyde, protein, total microbes, of tofu $5 \%$ formalin soaked $84.214 \mathrm{mg} / \mathrm{kg}, 3,7939 \%, 1,6 \times 10^{4}(\mathrm{cfu} / \mathrm{ml})$. The best treatment in decreasing formalin content is $100 \%$ aloe vera with 90 minute immersion, the remainder of formalin 28.678 ppm or $67 \%$ decreased levels of formalin in tofu, 5,5815\% protein, total microbes $0,3,6$, and 9 (days) were $7,0 \times 10^{4}, 1,8 \times 10^{5}, 9,3 \times 10^{5}$, and $1,5 \times 10^{6}$ (cfu/ml). Aloe vera contains saponins that act as surfactants capable of reducing formaldehyde in tofu.
\end{abstract}

Keywords: Aloe vera, formalin, lemon, tofu

\section{PENDAHULUAN}

Tahu adalah salah satu produk kedelai yang banyak diminati oleh negara-negara di Asia khususnya Indonesia. Tahu mengandung sekitar $50 \%$ protein dan sumber kalsium yang baik. Konsumsi produk kedelai secara teratur mengurangi risiko penyakit kronis seperti kanker, penyakit jantung, dan stroke (Jooyandeh, 2011). Kelemahan tahu, yaitu tahu diklasifikasikan sebagai makanan yang mudah rusak, yang dikaitkan dengan umur simpannya yang pendek. Oleh sebab itu, untuk menghindari kerugian besar, produsen sering menambahkan bahan pengawet seperti formalin. Formalin adalah salah satu bahan pengawet yang dilarang secara resmi untuk digunakan sebagai bahan pengawet makanan, sesuai peraturan Menteri Kesehatan Republik Indonesia No. 033 tahun 2012 tentang Bahan

Tambahan Pangan (Matondang, et al., 2015). Formalin adalah senyawa reaktif yang dapat mengikat senyawa dalam bahan makanan, seperti protein, lemak, dan karbohidrat. Mekanisme formalin sebagai pengawet adalah ketika formaldehida bereaksi dengan protein untuk membentuk sekuens antara protein yang berdekatan. Sebagai hasil dari reaksi ini, protein mengeras dan tidak dapat larut (Shita, 2016). Protein yang tidak bisa dicerna makanan akan menjadi bahan asing (antigen) bagi tubuh, sehingga menimbulkan respon imun (Wikanta, 2011).

Pemberian formalin pada udang putih (Wikanta, 2011) telah terbukti mempengaruhi 
nilai gizi protein diet (asam amino dan PER) dan merusak organ hewan percobaan.

Formalin juga merupakan sumber reaktif oksigen (SOR) dan radikal bebas eksogen. Vitamin $\mathrm{E}$ dan vitamin $\mathrm{C}$ memiliki potensi dalam hal menangkap senyawa oksigen reaktif. Berdasarkan laporan kejadian luar biasa yang diterima POM pada tahun 2016, 6.136 orang terpapar makanan yang diduga menyebabkan keracunan, 3.413 orang sakit, dan 8 kematian (BPOM, 2017).

Dengan demikian, makanan formalin merupakan ancaman bagi kesehatan dan keselamatan kehidupan masyarakat, baik dalam jangka pendek maupun jangka panjang. Oleh karena itu, harus ada upaya yang harus dilakukan untuk memastikan bahwa makanan yang dikonsumsi bebas dari formalin, salah satunya menggunakan bahan alami seperti lidah buaya dan lemon yang sangat mudah ditemukan di Indonesia.

Senyawa saponin yang terkandung dalam lidah buaya berpotensi menurunkan formalin dengan cara perendaman. Cara saponin bekerja pada gel lidah buaya dapat menurunkan tingkat formalin yang dikenal sebagai reaksi saponifikasi (proses pembentukan sabun) di mana sabun tersebut termasuk dalam kelompok surfaktan (Gusviputri, 2013). Berdasarkan penelitian sebelumnya oleh Jannah, et al., (2014) menunjukkan bahwa perendaman larutan lengkuas (Alpinia galanga) $20 \%$ selama 60 menit menurunkan kadar formalin sebesar $64 \%$ pada udang putih.

Asam sitrat digunakan sebagai bahan pembersih yang ramah lingkungan. Aktivitas antioksidan dari sampel lemon (Citrus limon L) dilaporkan oleh Ali, et al., 2010. Kehadiran antioksidan yang ditemukan dalam lemon menjadi salah satu faktor pendukung penurunan kandungan formalin dalam tahu formalin.

Berdasarkan beberapa penelitian sebelumnya yang menunjukkan keefektifan saponin untuk mengurangi senyawa formalin, maka penelitian ini bertujuan untuk melihat pengaruh perbandingan sari lidah buaya dan sari lemon dalam mereduksi formalin serta pengaruhnya terhadap masa simpan tahu.

\section{METODE}

\section{Alat dan Bahan}

Peralatan yang digunakan dalam penelitian ini adalah labu analitik kjedahl 100 $\mathrm{ml}$, peralatan distilasi (Gerhard), buret, erlenmeyer $100 \mathrm{ml}$, volumetrik labu $100 \mathrm{ml}$, volume pipet $10 \mathrm{ml}$, cawan petridish, autoclave (GEA), dan HPLC (shimadzu). Bahan yang digunakan dalam penelitian ini adalah kacang kedelai diperoleh dari pasar lokal. Lidah buaya jenis Barbadensis Miller. Buah lemon timur tengah yang diperoleh dari perkebunan lemon di Jl. Bunga Sedap Malam Sempakata, Medan Selayang. Bahan kimia yang digunakan dalam penelitian ini adalah $\mathrm{H}_{2} \mathrm{SO} 4$ (merck), $\mathrm{NaOH}$ $50 \%$ (merck), asam borat (merck), indikator metil merah (merck), HCL (merck), aquadest, formaldehida $37 \%$ (merck), dinitrofenilhidrazin $0,1 \%$, diklorometana (merck), metanol (smart lab), plat count agar (oxoid).

\section{Metode Eksperimen \\ Desain Eksperimen}

Penelitian ini menggunakan Rancangan Acak Lengkap (RAL) faktorial dan Rancangan Acak Lengkap (RAL) nonfaktorial. RAL faktorial terdiri atas 2 faktor. Faktor pertama (perbandingan sari lidah buaya dan sari lemon) terbagi menjadi 6 taraf, yaitu 100:0, 80:20, 60:40, 40:60, 20:80, dan 0:100 (\%). Faktor kedua (lama perendaman) terbagi atas 3 taraf, yaitu 30, 60, dan 90 (menit). RAL nonfaktorial perlakuan terhadap lama penyimpanan, yaitu $0,3,6$, dan 9 (hari). Dilakukan 3 kali ulangan untuk setiap analisa.

\section{Prosedur Kerja}

Penelitian ini menggunakan dua tahapan. Tahap pertama dimulai dengan pembuatan simulasi tahu, pembuatan larutan 
formalin $1 \%$, pembuatan sari lidah buaya dan sari lemon.

\section{Persiapan Pembuatan Tahu}

Disortasi kedelai dicuci, direndam dalam air bersih selama 12 jam. Kacang kedelai dihancurkan dengan menggunakan blender, ditambahkan air hangat dengan rasio kedelai dan air adalah 1:2. Disaring, filtrat dipanaskan, diaduk, ditambahkan asam asetat sampai terbentuk gumpalan. Tahu siap untuk dipadatkan dan untuk digunakan.

\section{Pembuatan Sari Lidah Buaya dan Sari Lemon}

Pembuatan sari lidah buaya. Lidah buaya dicuci, dilepaskan lapisan kuning tepat di bawah kulit dan dibuang. Diblansing, dilumatkan dengan blender, disaring. Pembuatan jus lemon, Potong lemon menjadi dua bagian, diperas, disaring sehingga menghasilkan sari yang jernih. Masing-masing sari disesuaikan dengan persentase yang digunakan dalam penelitian, yaitu 100, 80, 60, 40, 20, dan $0(\%)$.

\section{Perendaman Tahu ke dalam Sari Lidah Buaya dan Sari Lemon}

Tahu formalin direndam ke dalam campuran jus lidah buaya dan jus lemon dengan perbandingan masing masing 100\%:0\% (A1) 80\%:20\% (A2), 60\%:40\% $\begin{array}{llll}\text { (A3) } \quad 40 \%: 60 \% & \text { (A4), } 20 \%: 80 \% & \text { (A5) }\end{array}$ 0\%:100\% (A6) yang kemudian direndam selama 30 (L1), 60 (L2), dan 90 (L3) (menit) setiap perlakuan dianalisis untuk kandungan formalin, kandungan protein, dan total mikroba Perlakuan terbaik diperoleh dari penurunan kandungan formalin terbesar yang kemudian dilanjutkan untuk perlakuan penyimpanan. Tahu akan disimpan dalam refrigerator (lemari pendingin) dengan suhu $10^{\circ} \mathrm{C}$ untuk lama penyimpanan (M) untuk hari 0 (M1), 3 (M2), 6 (M3), dan 9 (M4) yang kemudian akan dianalisis terhadap total mikroba.

\section{Analisis HPLC untuk Penentuan Formaldehida}

Protokol yang dimodifikasi untuk mendeteksi formaldehid dalam tahu dengan instrumen HPLC (Model SPD-M20 A) berdasarkan metode yang dijelaskan oleh Li et al., (2007) sebagai berikut:

\section{Preparasi Sampel}

Tahu dipotong berbentuk dadu dan dihaluskan dengan menggunakan mortal dan alu. Sampel ditimbang sebanyak $\pm 5 \mathrm{~g}$ dan ditambahkan $50 \mathrm{~mL}$ aqua demineralisasi (DM), dipanaskan pada suhu $96^{\circ} \mathrm{C}$ selama 30 menit. Sampel disaring menggunakan kertas saring untuk mendapatkan filtrat yang mengandung formaldehid, kemudian filtratnya disentrifugasi pada $3000 \mathrm{rpm}$ selama 10 menit dan diperoleh supernatan, dimasukkan ke dalam botol dan dilakukan degassing menggunakan alat Branson 5200 Ultrasonic Cleaner.

\section{Derivatisasi Formaldehida}

Sampel filtrat dan larutan standar (20 ppm, 60 ppm, 80 ppm, dan 100 ppm) diambil masing-masing $1 \mathrm{~mL}$. Sebanyak $0,5 \mathrm{~mL}$ larutan DNPH 0,1\% ditambahkan, kemudian diekstraksi menggunakan diklorometana. Setelah fase diklorometana diguncang, diambil dan fasa air dikeluarkan. Diklorometana diuapkan dan residu evaporasi dilarutkan dengan $1 \mathrm{~mL}$ metanol. Larutan kemudian disaring menggunakan filter membran $0,45 \mu \mathrm{m}$ sebelum injeksi. Untuk setiap sampel dua ulangan dianalisis. Hasil dinyatakan sebagai $\mathrm{mg} / \mathrm{kg}$.

\section{Kondisi Analitik HPLC}

HPLC yang digunakan adalah HPLC shimadzu tipe LC-20AT/ SPD-20A, yang terdiri dari tipe pompa LC-20AT, tipe kolom VP-ODS (250 x 4,6 mm), UV-Vis mendeteksi SPD-20A. Volume sampel diatur pada $20 \mu \mathrm{l}$ dan panjang gelombang detektor penyerapan diatur pada $355 \mathrm{~nm}$ dan suhu oven pada suhu 
$30^{\circ} \mathrm{C}$. Pemisahan dicapai dengan menggunakan elusi isokratik dengan campuran air/ metanol $(35: 65 \mathrm{v} / \mathrm{v})$. Total run time adalah 10 menit. Daerah puncak digunakan untuk perhitungan formaldehida kuantitatif.

\section{Penentuan Kandungan Protein (AOAC, 1970)}

Sampel tahu sebanyak $0,5 \mathrm{~g}$ dimasukkan ke dalam labu kjedahl, ditambahkan $1,5 \mathrm{~g}$ selenium dan $15 \mathrm{ml} \mathrm{H}_{2} \mathrm{SO} 4$, dilarutkan dalam ruang asam, diikuti pemanasan selama 1 jam, didinginkan. Kemudian diencerkan dengan aquadest dalam labu ukur, suling dengan penambahan $20 \mathrm{ml} \mathrm{NaOH} \mathrm{50 \% .} \mathrm{Produk}$ distilasi diakomodasi dengan $10 \mathrm{ml}$ asam borat dan 3 tetes indikator metil merah. Penyulingan dilakukan sampai tempat penampungan mencapai $100 \mathrm{ml}$. Kemudian hasil distilasi dititrasi dengan $0,02 \mathrm{~N} \mathrm{HCl}$ sampai terbentuk warna pink (satuan dalam \%). Persen (\%) didapat dari jumlah titrasi (ml) $\mathrm{HCl} / 100 \mathrm{ml}$.

\section{Penentuan Total Mikroba (Fardiaz, 1989).}

Menguji jumlah mikroba dengan menggunakan metode pelat yang dihitung atau "pour plate". Sampel tahu ditimbang $5 \mathrm{~g}$ dan dimasukkan ke dalam labu erlenmeyer yang mengandung $45 \mathrm{ml}$ garam fisiologis steril, diencerkan secara desimal mulai $10^{-1}$ sampai $10^{-6}$, kemudian masing-masing sebanyak $1 \mathrm{ml}$ suspensi dimasukkan ke dalam cawan petri steril, dituangkan 12-15 ml larutan Plate Count Agar (PCA) hangat $\left(40-50^{\circ} \mathrm{C}\right)$, homogenkan, cawan petri dibalikkan apabila telah mengeras dan diinkubasikan pada $37^{\circ} \mathrm{C}$ selama 48 jam.

Setelah 48 jam dihitung jumlah koloni mikroba yang terkandung di dalam cawan dengan ketentuan jumlah koloni dihitung antara 30-300.

\section{HASIL DAN PEMBAHASAN \\ HASIL \\ Pengaruh Konsentrasi Sari Lidah Buaya dan Sari Lemon Terhadap Parameter Mutu Tahu}

Hasil penelitian menunjukkan bahwa perbandingan sari lidah buaya dan sari lemon memberikan pengaruh sangat nyata terhadap kadar formalin (ppm), total mikroba $(\log \mathrm{CFU} / \mathrm{ml})$, dan kadar protein (\%). Pengaruh perbandingan sari lidah buaya dan sari lemon terhadap parameter mutu tahu yang diamati dapat dilihat pada Tabel 1, sedangkan pengaruh lama perendaman terhadap parameter mutu tahu dapat dilihat pada Tabel 2. Tabel 3 menunjukkan pengaruh lama penyimpanan terhadap total mikroba tahu.

Tabel 1 menunjukkan bahwa kadar formalin tertinggi diperoleh pada perlakuan A6 (0\%:100\%) sari lidah buaya $0 \%$ dan sari lemon $100 \%$ sebesar 65,161 (ppm) hanya dapat menurunkan kadar formalin sebesar $22,63 \%$ dan terendah pada perlakuan A1 (100\%:0\%) sari lidah buaya $100 \%$ dan sari lemon $0 \%$, sebesar 36,163 (ppm). Total mikroba yang tertinggi diperoleh pada perlakuan A1 (100\%:0) sari lidah buaya 100\% dan sari lemon $0 \%$, yaitu $5,083 \quad(\log \mathrm{CFU} / \mathrm{ml})$ sedangkan yang terendah pada perlakuan A6 (0\%:100\%) sari lidah buaya $0 \%$ dan sari lemon $100 \%$, yaitu 2,861 (logCFU/ml). Kadar protein pada perlakuan A6 (0\%:100\%) sari lidah buaya $0 \%$ dan sari lemon $100 \%$, menghasilkan kadar protein terendah dan kadar protein tertinggi pada sari lidah buaya $100 \%$ dan sari lemon $0 \%$.

Tabel 2 menunjukkan bahwa semakin lama perendaman, maka kadar formalinnya semakin menurun. Lama perendaman 90 menit dapat menurunkan sebesar 50,42\% dengan sisa formalin sebesar 41,752 (ppm). Total mikroba tertinggi diperoleh pada perlakuan L3 (90 menit), yaitu 4,640 (logCFU/ml) sedangkan yang terendah diperoleh pada perlakuan L1 (130 menit), yaitu 3,978 (logCFU/ml).

Tabel 3 menunjukkan bahwa perlakuan A1L3 adalah perlakuan terbaik karena persentase penurunan formalinnya terbesar dari perlakuan lainnya. Total mikroba selama penyimpanan semakin meningkat dikarenakan daya awet oleh formalin semakin hilang. 
Tabel 1. Pengaruh Perbandingan Sari Lidah

Buaya dan Sari Lemon Terhadap Parameter

Tahu

\begin{tabular}{cccc}
\hline \multirow{2}{*}{ Perlakuan } & $\begin{array}{c}\text { Kadar } \\
\text { formalin } \\
(\mathrm{ppm})\end{array}$ & $\begin{array}{c}\text { Total mikroba } \\
(\log \text { CFU/ml })\end{array}$ & $\begin{array}{c}\text { Kadar protein } \\
(\%)\end{array}$ \\
\hline A1 & $36,163^{\mathrm{g}}$ & $5,083^{\mathrm{b}}$ & $5,541^{\mathrm{b}}$ \\
A2 & $41,093^{\mathrm{f}}$ & $4,968^{\mathrm{b}}$ & $5,395^{\mathrm{c}}$ \\
A3 & $46,499^{\mathrm{e}}$ & $4,858^{\mathrm{c}}$ & $5,232^{\mathrm{d}}$ \\
A4 & $53,312^{\mathrm{d}}$ & $4,301^{\mathrm{d}}$ & $4,856^{\mathrm{e}}$ \\
A5 & $57,976^{\mathrm{c}}$ & $4,170^{\mathrm{d}}$ & $4,530^{\mathrm{f}}$ \\
A6 & $65,161^{\mathrm{b}}$ & $2,861^{\mathrm{e}}$ & $4,337^{\mathrm{g}}$ \\
Tahu & $0,000^{\mathrm{h}}$ & $5,552^{\mathrm{a}}$ & $6,331^{\mathrm{a}}$ \\
kontrol & & $0,000^{\mathrm{f}}$ & $3,800^{\mathrm{h}}$ \\
Tahu & $84,214^{\mathrm{a}}$ & & \\
formalin & & &
\end{tabular}

\section{Keterangan :}

$\mathrm{A} 1=$ sari lidah buaya $:$ sari lemon (100\%:0\%)

$\mathrm{A} 2=$ sari lidah buaya $:$ sari lemon $(80 \%: 20 \%)$

$\mathrm{A} 3=$ sari lidah buaya:sari lemon $60 \%: 40 \%$ )

$\mathrm{A} 4=$ sari lidah buaya $:$ sari lemon $(40 \%: 60 \%)$

A5 $=$ sari lidah buaya $:$ sari lemon $(20 \%: 80 \%)$

A6=sari lidah buaya : sari lemon (0\%:100\%)

Tabel 2. Pengaruh Lama Perendaman terhadap Parameter Tahu

\begin{tabular}{cccc}
\hline & \multicolumn{3}{c}{ Parameter Tahu } \\
\cline { 2 - 4 } Perlakuan & $\begin{array}{c}\text { Kadar } \\
\text { formalin } \\
(\%)\end{array}$ & $\begin{array}{c}\text { Total mikroba } \\
(\text { log CFU/ml })\end{array}$ & Kadar protein $(\%)$ \\
\hline L1 & $58,457^{\mathrm{b}}$ & $3,978^{\mathrm{c}}$ & $4,817^{\mathrm{d}}$ \\
L2 & $49,892^{\mathrm{c}}$ & $4,502^{\mathrm{b}}$ & $4,968^{\mathrm{c}}$ \\
L3 & $41,752^{\mathrm{d}}$ & $4,640^{\mathrm{b}}$ & $5,161^{\mathrm{b}}$ \\
& & & \\
Tahu & & $5,552^{\mathrm{a}}$ & $6,331^{\mathrm{a}}$ \\
kontrol & $0,000^{\mathrm{e}}$ & & $3,800^{\mathrm{f}}$ \\
$\begin{array}{c}\text { Tahu } \\
\text { formalin }\end{array}$ & $84,214^{\mathrm{a}}$ & $0,000^{\mathrm{d}}$ & \\
\hline
\end{tabular}

Keterangan:

$\mathrm{L} 1=$ Lama perendaman 30 menit

L2= Lama perendaman 60 menit

L3= Lama perendaman 90 menit
Tabel 3. Pengaruh Lama Penyimpanan terhadap Total Mikroba Tahu

\begin{tabular}{cccc}
\hline Perlakuan & 3 Hari & 6 hari & 9 hari \\
\hline $\begin{array}{c}\text { Tahu } \\
\text { kontrol }\end{array}$ & $6,4206^{\mathrm{a}}$ & $6,9135^{\mathrm{a}}$ & $7,1703^{\mathrm{a}}$ \\
& & & \\
A1L3 & & & \\
(sari lidah & & & \\
buaya & $5,2987^{\mathrm{b}}$ & $5,9215^{\mathrm{b}}$ & $6,2208^{\mathrm{b}}$ \\
$\quad \begin{array}{l}\text { 100\%, } \\
\text { perendaman }\end{array}$ & & & \\
90 menit) \\
$\begin{array}{c}\text { Tahu } \\
\text { formalin }\end{array}$ & $3,8819^{\mathrm{c}}$ & $4,6910^{\mathrm{c}}$ & $5,7864^{\mathrm{c}}$ \\
\hline
\end{tabular}

\section{PEMBAHASAN}

Pengaruh Konsentrasi Sari Lidah Buaya dan Sari Lemon serta Lama Perendaman terhadap Kadar Formalin Tahu

Perlakuan A1 (100\%:0\%), yaitu sari lidah buaya $100 \%$ adalah perlakuan terbaik, karena menurunkan kadar formalin terbesar. Hal tersebut menunjukkan bahwa persentase sari lidah buaya yang tinggi memiliki kemampuan mereduksi kandungan formalin yang lebih baik jika dibandingkan dengan sari lemon, dikarenakan adanya kandungan saponin yang tinggi di dalam lidah buaya.

Wirawan, et al., (2017) menemukan bahwa saponin yang terkandung dalam daun singkong mampu mereduksi kandungan formalin pada udang putih. Rosida, (2002), kandungan saponin pada lidah buaya sebesar $500 \mu \mathrm{g} / \mathrm{ml}$.

Saponin yang terkandung pada lidah buaya mereduksi formalin dalam tahu melalui reaksi saponifikasi. Zat surfaktan dalam saponin bersifat ampifatik yaitu memiliki gugus hidrofobik (non polar) dan hidrofilik (polar), sehingga dapat membentuk emulsi air dan formalin. Saponin berperan sebagai emulgator. Senyawa saponin teradsorbsi ke daerah antar fase dan mengikat partikel formaldehida, sehingga diperoleh kestabilan emulsi dari gugus polar. Setelah formalin terikat dengan senyawa saponin, maka saponin akan larut dan membentuk misel (micelles). Bagian misel berinteraksi dengan air dan formalin, sehingga formalin dapat larut 
bersama air (Dwimayasanti, dkk., 2014). Semakin lama perendaman sari lidah buaya terhadap tahu yang berformalin, maka semakin banyak ikatan-ikatan formalin terputus dari struktur komponen tahu sehingga kadar formalin semakin rendah.

\section{Pengaruh Konsentrasi Sari Lidah Buaya dan} Sari Lemon serta Lama Perendaman terhadap Total Mikroba Formalin Tahu

Tabel 1 menunjukkan bahwa pada tahu berformalin, jumlah mikroba adalah 0,00 log $\mathrm{CFU} / \mathrm{ml}$ atau dapat dikatakan bahwa tahu berformalin tidak mengandung mikroba. Hal tersebut disebabkan karena formalin mampu melindungi bahan makanan dari kerusakan yang disebabkan oleh mikroba. Formalin mampu menghambat pertumbuhan mikroba aerobik pada konsentrasi yang sangat rendah

Tabel 2 menunjukkan tahu yang diberi perlakuan perendaman dengan sari lidah buaya dan sari lemon, diketahui bahwa mikroba paling sedikit dijumpai pada perlakuan A6 (0\%:100\%), yaitu sari lidah buaya $0 \%$ dan sari lemon $100 \%$ dan lama perendaman 30 menit. Hal ini dikarenakan kandungan formalin dalam sampel masih tinggi, sehingga formalin masih mampu untuk menghambat pertumbuhan mikroba. Penelitian Ramesh, et al., (2017) menunjukkan bahwa pada larutan formalin $10 \%$ dapat ditumbuhi oleh mikroba CoNS dan E.coli. Bakteri anaerobik umumnya tidak memiliki pengaruh terhadap formalin, karena dinding selnya yang kompleks.

Jumlah mikroba tertinggi diperoleh pada perlakuan A1 (100\%:0\%) sari lidah buaya $100 \%$ dan $0 \%$ sari lemon dan lama perendaman L3 (90 menit). Tingginya jumlah mikroba tersebut dikarenakan banyaknya jumlah formalin yang terurai oleh senyawa yang terkandung dalam lidah buaya, sehingga ikatan silang antara protein dan fomaldehid terlepas. Pelepasan ikatan silang tersebut menyebabkan tingginya kandungan protein yang dapat digunakan oleh mikroba sebagai substrat untuk pertumbuhannya. Menurut Hershey dan Chase (2017) protein dan asam nukleat merupakan media pertumbuhan yang sangat baik bagi mikroorganisme.
Pengaruh Konsentrasi Sari Lidah Buaya dan Sari Lemon serta Lama Perendaman terhadap Kadar Protein Formalin Tahu

Tabel 1 menunjukkan pada perlakuan kontrol, tahu memiliki kandungan protein sebesar $6,331 \%$ dan ketika diberi formalin kadar protein menurun menjadi $3,80 \%$. Penurunan kadar protein tersebut dikarenakan adanya kerusakan protein oleh senyawa formaldehida. Kereaktifan formalin dapat menyebabkan terbentuknya ikatan silang dengan protein, di mana formaldehid bereaksi dengan gugus amino $\mathrm{N}$-terminal dan rantai samping sistein, histidin, lisin, triptofan, dan arginin (Hoffman, et al., 2015) menyebabkan terbentuknya senyawa methylene $\left(-\mathrm{CH}_{2}-\right)$.

Setelah dilakukan perendaman terhadap tahu berformalin dengan berbagai konsentrasi sari lidah buaya dan sari lemon, diketahui bahwa terjadi peningkatan kadar protein pada tahu tersebut. Peningkatan tertinggi diperoleh pada perlakuan A1 (100\%:0\%) yaitu sari lidah buaya $100 \%$ dan $0 \%$ sari lemon di mana kadar protein tahu sebesar $5,541 \%$ dan peningkatan terendah pada perlakuan A6 (0\%:100\%), yaitu sari lidah buaya $0 \%$ dan sari lemon $100 \%$ di mana kadar protein tahu sebesar $4,337 \%$.

Hal tersebut disebabkan adanya penurunan kadar formalin pada tahu setelah direndam sari lidah buaya dan sari lemon. Penurunan kadar formalin menyebabkan terputusnya ikatan silang antara protein dan formaldehid yang membentuk methylene, sehingga struktur protein kembali pada kondisi semula dan kadar protein tahu menjadi meningkat.

Senyawa methylene dapat terurai kembali melalui reaksi hidrolisis membentuk protein dan formalin (Purawisastra dan Sahara, 2011). Adapun reaksi formalin dan protein dapat dilihat pada Gambar 1. 


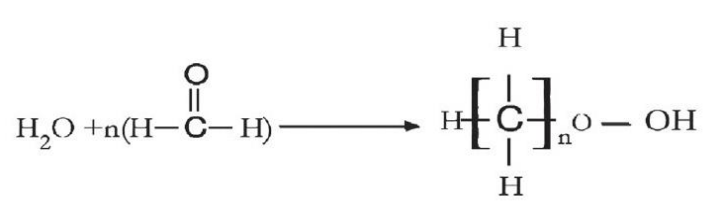

Water + Formaldchyde

Formaldchyde Polymer

$$
\mathrm{H}\left[\begin{array}{l}
\mathrm{I} \\
\mathrm{I}
\end{array}\right]_{\mathrm{n}}^{\mathrm{I}} \mathrm{O}-\mathrm{OH}
$$

Formaldehyde Polymer

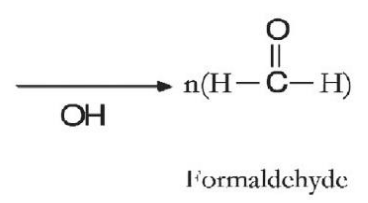

Gambar 1. Reaksi formalin dengan protein (Thavarajah, et al., 2012).

\section{Total Mikroba Selama Penyimpanan}

Perlakuan yang terbaik adalah perlakuan yang mampu menurunkan kadar formalin terbesar, yaitu A1 (sari lidah buaya 100\%). Pengaruh lama penyimpanan terhadap total mikroba tahu dapat dilihat pada Tabel 3.

Pada penyimpanan 3 hari didalam refrigerator pada suhu $10^{\circ} \mathrm{C}$, diketahui bahwa pada tahu yang diberi perlakuan formalin dijumpai pertumbuhan mikroba. Pada penyimpanan selanjutnya pada refrigerator dengan suhu $10^{\circ} \mathrm{C}$ jumlah mikroba semakin bertambah. Hal ini dikarenakan selama penyimpanan, formalin mengalami degradasi, sehingga kandungan formalin menjadi menurun. Rendahnya kandungan formalin memungkinkan mikroba untuk tumbuh dalam tahu, meskipun masih mengandung formalin. Bakteri anaerobik umumnya tidak berpengaruh terhadap adanya formalin, karena dinding selnya yang kompleks, di mana membran bagian luarnya bertindak sebagai penghalang permeabilitas dalam membatasi atau mencegah masuknya bahan kimia.

\section{KESIMPULAN}

Dalam penelitian ini efektifitas sari lidah buaya dengan sari lemon dilakukan dengan berbagai konsentrasi didapatkan hasil pada sari lidah buaya $100 \%$ mampu menurunkan kadar formalin sebesar $57,05 \%$ dari kadar formalin $84,214 \mathrm{mg} / \mathrm{kg}$ menjadi $36,163 \mathrm{mg} / \mathrm{kg}$. Kehilangan kadar protein terendah setelah perendaman dengan sari lidah buaya $100 \%$, pada kontrol sebesar 6,331\%, menjadi 5,541\%. Hal ini bersifat linear antara jumlah mikroba yang tumbuh dengan lama perendaman dengan sari lidah buaya $100 \%$. Hal ini berkaitan dengan banyaknya jumlah formalin yang terurai oleh senyawa yang terkandung dalam lidah buaya, menyebabkan ikatan silang antara protein dan fomaldehid terlepas.

\section{DAFTAR PUSTAKA}

Ali, A. M., L. I., Devi, V., Nayan, K. H. V., Chanu, and L. Ralte. 2010. Antioxidant Activity of Fruits Available in Aizawl Market of Mizoram. India. International Journal of Biological Pharmaceutical 1(2):7681.

BPOM, 2017. Siaran Pers Gerakan Masyarakat Hidup Sehat Sadar Pangan Aman Kerja Bersama Menuju Indonesia Pangan Aman. http://www.pom.go.id. Diakses 23 November 2017.

Damayanti, E., W. F., Ma'ruf dan I. Wijayanti. 2014. Efektivitas Kunyit (Curcumalu nga Linn) sebagai Pereduksi Formalin pada Udang Putih Selama Penyim panan Dingin. Jurnal Pengolahan dan Bioteknologi Hasil Perikanan. 3(1):98-107.

Gusviputri, A. N., P. S. Melianan, Aylianawati, dan S. Indrswati. 2014. Pembuatan Sabun dengan Lidah Buaya sebagai Antiseptik Alami. Widya Teknik. 12(1):11-21.

Hershey, A. D., and M. Chase. 2017. Independent Functions of Viral Protein and Nucleic Acid in Growth of Bacteriophage Bayern Munchen: Springer.

Hoffman. E. A., B. L. Frey, L. M. Smith, and D.T. Auble. 2015. Formaldehyde Crosslinking: A Tool For The Study of Chromatin Complexes. Journal Biology Chemical. 290(44):2640426411.

Jannah, M., W. F. Ma;ruf, dan T. Surti. 2014. Efektivitas Lengkuas sebagai Pereduksi Kadar Formalin pada Udang Putih Selama Penyimpanan Dingin. 3(1):70-79.

Jooyandeh, H. 2011. Soy Products as Healthy and Functional Foods. Journal of Scientific Research, 7(1):71-80. 
Li, J., J. Zhu and L. Ye., 2007. Determination of Formaldehyde in. Squid by High Performance Liquid Chromatography. Asia Pac. J. Clin. Nutr. 16(1):127-130.

Purawisastra, S. dan E. Sahara, E. 2011. Penyerapan Formalin oleh Beberapa Jenis Bahan Makanan Serta Penghilangannya dalam Air Panas. Jurnal Penelitian Gizi dan Makanan. 34(1).

Ramesh, G. A., R Katiyar, A. Sujath B. Raj, Gupta, and A. Kumar, 2017.

Detection of Microorganisms on Formalin-Fixed and Stored Pathology Tissues: A Microbiology Study Journal of Oral and Maxillofacial Pathology. 21(1):64.

Rosida, J. 2002. Uji Saponin dalam Lidah Buaya, Limbah Buah Mengkudu dan Daun Mimba Makalah Laborato rium Penelitian Temu. Teknis Fungsional. Non Peneliti. Balai Ternak. Ciawi. Bogor.

Shita, A. E., 2016. Selektivitas Metode

Analisis Formalin Secara Spektrofotometri..dengan Pereaksi Schiff's Skripsi.Yogyakarta; Universitas Negeri Yogyakarta.

Thavarajah, R., V. K. Mudimbaimannar, J. Elizabeth, U. K. Rao, and K. Ranganathan, 2012. Chemical and Physical Basics of Routine Formaldehyde Fixation. Journal of Oral and Maxillofacial Pathology. 16(3): 400-405.

Wikanta, W. 2011, Pengaruh Penambahan Belimbing wuluh dan Perebusan terhadap Residu Formalin dan Profil Protein Udang Putih Berformalin serta Pemanfaatanya sebagai Sumber Pendidikan Gizi dan Keamanan Pangan pada Masyarakat, Pascasarjana FK. UB, Surabaya.

Wirawan, Tantalu, L., and Suliana, G., 2017. Efektivitas Daun Singkong Malang sebagai Pereduksi Kadar Formalin pada Udang Putih. Jurnal Penelitian Penelitian Terapan. 17(3):170-175. 